\title{
FACTORS AFFECTING THE CHOICE OF EQUITY - BASED MODE BY FOREIGN FIRMS ENTERING KAZAKHSTAN
}

\author{
Aigerim Abuova \\ Hankuk University of Foreign Studies \\ Wonchan Ra \\ Hankuk University of Foreign Studies
}

\begin{abstract}
Choice of modes is a critical decision that firms conducting equity-based foreign direct investment must make since it has a significant effect on performance. Entry mode choice has been a major topic in international business research up to now. As the largest economy in Central Asia, Kazakhstan became one of the main destinations for foreign direct investment in this area while transitioning to a marketbased economy after gaining independence from the Soviet Union in 1991. This paper investigates the main firm- and country-specific factors that affect the choice of equity-based entry modes of foreign investors entering Kazakhstan between a joint venture (JV) and a wholly-owned subsidiary (WOS). We establish hypotheses regarding the effects of such factors on the mode choice and empirically test the hypotheses with secondary data on foreign companies' entry in Kazakhstan, using binomial logit regression analysis.
\end{abstract}

Keywords: Foreign market entry mode, Equity-based entry mode, Joint venture, Wholly-owned subsidiary, Kazakhstan.

DOI: http://dx.doi.org/10.15549/jeecar.v5i2.233

\section{INTRODUCTION}

For any firms entering into foreign markets, choice of entry mode has significant implications for firm performance, and once an entry mode is chosen, it is difficult to change without additional costs and losses (Contractor, 2001; Root, 1987). Therefore, choice of entry mode has been one of the most studied research areas in the international business literature (Canabal \& White, 2008; Werner, 2002). Recently some scholars (e.g., Shaver, 2013) have discounted the value of research on entry modes. However, antecedents and consequences of entry mode choice are still an important research topic, warranting more entry mode studies (Hennart \& Slangen, 2015).

As with other post-Soviet republics, since the early 1990s after regaining independence from the Soviet Union, Kazakhstan has gone through a significant transformation process, moving to a market-based economy and attracting much foreign direct investment (FDI). However, the transition process in the country may have generated an unstable and adverse environment with high transaction costs for foreign investors. Therefore, multinational enterprises (MNEs) entering transition economies need to consider characteristics of such economies and adjust entry mode strategies to the local institutions. According to Meyer (2001), the transition from socialism to capitalism and more active involvement of post-Soviet republics in the world economy has promoted international trade and capital flows in the region despite the difficulties encountered in each country. 
Kazakhstan is a country abundant with diverse natural resources such as petroleum, natural gas, coal, iron ore, copper, gold, uranium, etc. It ranks second to Russia in its reserves of mineral resources in the world. Its economy heavily depends on oil and mineral industries and the largest portion of its exports is attributed to petroleum and natural gas. Kazakhstan has now the 15th largest proven oil reserves in the world, owning 3\% of global reserves (Vakulchuk \& Overland, 2018). Kazakhstan joined Eurasian Customs Union in 2010, a regional economic bloc led by Russia, now succeeded by Eurasian Economic Union, to expand its market size and promote foreign investment flow into the country (Lagutina, 2018).

In Kazakhstan, thanks to privatization for the three years from 1994 to 1997, FDI into the country surged from $\$ 600$ million in 1994 to $\$ 2.1$ billion in 1997 according to UNCTAD reports (UNCTAD, various issues). Then it continued to grow, especially since the commodity price boom in 2004 (Baigabylova, 2012), reaching $\$ 12.0$ billion in 2007, $\$ 16.8$ billion in 2008, and $\$ 13.6$ billion in 2012. In more recent years it showed a decreasing trend, but again surged to $\$ 16.7$ billion in 2016 (World Bank, 2017). Among Central Asian countries, Kazakhstan, from 1991 and 2016, attracted 65\% of the total FDI into the region, while Uzbekistan received 19\%, Turkmenistan 12\%, and Kyrgyzstan and Tajikistan, which were less than $2 \%$.

Despite growing significance, FDI flows to Kazakhstan are one of the most underresearched areas in the studies of the Central Asian economy. Also, the entry mode choices of foreign investors in this country, especially their ownership strategy, have been highly ignored. The aim of this study is to investigate the effects of several key determinants of firm- and country-level variables on the equity-based entry mode choices of foreign investors entering Kazakhstan, by considering characteristics of foreign investors and home and host countries.

The paper is organized as follows. After the introduction, a survey of the existing literature on entry modes and factors influencing their choice are discussed. Then the theoretical framework and hypotheses on the determinants of choice of equity-based FDI entry modes of foreign firms are presented. Next, in the methodology section, the statistical model, empirical data, and measures for the dependent and independent variables are described. An empirical test of the hypotheses is conducted through a binomial regression using secondary data on 102 foreign companies in Kazakhstan, followed by discussion of test results. The paper ends with a discussion of the main findings and future research directions in the conclusion section.

\section{THE LITERATURE ON ENTRY MODES AND FACTORS INFLUENCING THEIR CHOICE}

Research on entry mode choice has been actively conducted since the 1980s (Canabal \& White, 2008). There are five broad distinctive foreign market entry modes in general discussed in the extant literature: exporting, licensing, franchising, joint ventures, and wholly owned subsidiaries. Exporting, licensing and franchising are non-equity modes, and joint ventures (JVs) and wholly owned subsidiaries (WOSs) are equity modes. An MNE may choose one of these entry modes to expand its business internationally.

Entry mode choices are often affected by trade-offs between four attributes including risks, returns, resource commitment, and the need for control (Anderson \& Gatignon, 1986; Agarwal \& Ramaswami, 1992; Contractor, 2001). It is expected that foreign firms face risks in exchange for a higher return on investment. Resource commitment means managerial and financial investments made by the foreign firms committed to achieve certain goals in a particular market. According to Anderson and Gatignon (1986), control refers to the firm's capacity and need to influence its subsidiary strategy and operations.

Exporting mode requires low resource commitment and as a result provides low control over operations and low return on investment. On the contrary, a wholly owned subsidiary needs high resource commitment and faces a high degree of risk, but offers high control and high return. For a single firm compared to a sole entry, a joint venture involves a lower investment amount. Therefore, the firm has lower risks, return and control over the local operations. Lastly, licensing and franchising entail relatively low resource commitment, risk, and return, but least control of local operations over the foreign licensing firm. 
In this study, we focus on the equity-based entry modes of joint ventures and wholly owned subsidiaries. Through joint ventures, foreign investors gain access to resources, and knowledge of local partners minimizes risks. There is a high possibility of conflicts between investors because of their diverging interests and possible opportunistic characteristics. A wholly owned subsidiary gives complete autonomy and control over a local firm. However, without the cooperation of local partners, risks and likelihood of failure increase as well as the liability of foreignness (Dikova \& Witteloostuijn, 2007).

In order to theoretically explain entry mode decisions, we rely on two main theories, that of transaction cost theory and institutional theory. Transaction cost theory (Coase, 1937) can help explain deciding between partial and full equity by comparing the potential costs and benefits of a wholly-owned subsidiary (WOS) to those of a joint venture (JV). According to the theory, the foreign firm's choice of a WOS would be because of the need to maintain internalization in the entry and provide for cost minimization. The firms entering transition economies usually encounter higher transaction costs because of underdeveloped law and regulatory systems and elevated levels of corruption and bureaucracy (Antal-Mokos, 1998; Thornton \& Mikheeva, 1996), insufficient knowledge on institutional mechanisms, local environment and local partners (Antal-Mokos, 1998), and weak protection of intellectual property (Oxley, 1999). These obstacles may lead to foreign firms' preference for hierarchical modes. Aulakh and Kotabe (1997) posit that securing full control over a subsidiary allows faster adjustment of former state-owned enterprises to free market demands.

Institutional theory has recently provided a promising perspective that might shed light on the determinants of which equity-based entry mode is chosen by foreign investors (Delios \& Beamish, 1999; Davis, Desai \& Francis, 2000; Meyer, 2001; Brouthers, 2002). The main tenet of the theory is that foreign firms adapt to the local institutional environment and hence increase legitimacy with those institutions. Scott (2008) identifies three kinds of institutions with different elements. The first is regulative institutions based on coercive enforcement mechanisms such as rules, orders and sanctions. The second is normative institutions based on binding expectations coming from common values and norms. The third is cultural-cognitive institutions based on common beliefs and shared logic of action.

From the perspective of institutional theory, MNEs making the decision between a WOS and a JV need to pay serious attention to legitimacy or social acceptance in the local environment. Transitional economies have unique institutional environments that are different from those of foreign countries (Ericson, 1991; Kornai, 1992; Peng, 1994). Foreign investors entering transition economies often encounter institutional peculiarities including a high degree of corruption and lack of transparency, requiring them to adapt their strategies to the local institutional environment. The process of transformation from a centrally planned economy to a free market-oriented one greatly affects the overall institutional stability and reliability in transition economies (Swaan, 1997; Meyer, 2001).

\section{THEORETICAL FRAMEWORK AND HYPOTHESES}

In recent years, an increasing number of scholars have looked at regulatory institutions in transition economies that affect decision making in foreign market entry modes of MNEs (Meyer, 2001; Dikova \& Witteloostuijn, 2005; 2007).

FDI in transition countries is considered challenging and risky because of local institutional instability and imperfections (Dikova \& Witteloostuijn, 2005). Kazakhstan has dealt with legal and institutional problems by establishing new rules, introducing competition policies, liberalizing markets, and implementing restructuring and privatization programs. Tugut and Lee (2007) posit that though the Kazakhstani government has performed several reforms recently, numerous problems and issues associated with legal and regulation environments still exist. Foreign investors entering transition economies like Kazakhstan encounter high transaction costs, because of a strong post-communist mentality, different working styles, and weaker institutional environments compared to their home countries.

The administrative and political systems in Kazakhstan may be perceived as democratic, though unstable and imperfect, leading to an insecure local environment with higher transaction costs. For a foreign firm alone, it is 
not an easy task to deal with this situation and one may seek a local partner to cooperate with, to effectively cope with the regulative uncertainty. Therefore, with the serious obstacles with the instability in the local regulative institutional environment in Kazakhstan, we hypothesize that a greater difference in regulative environments between the host and home country will encourage the choice of a JV by the foreign investor.

Hypothesis 1: The greater the regulative distance between the home and host country, the more likely the foreign firm investor will choose a JVover a WOS.

The normative institutional distance negatively influences the ability to gain legitimacy and to adopt practices (Ionascu, Meyer \& Estrin, 2004). Boyacigiller, Goodman and Phillips (2004) argue that the forces of the normative institutional environment are relatively more tacit and therefore harder to understand and to learn, compared with regulatory institutions. Foreign investors are more likely to join in relationship with local partners to overcome such difficulties and simplify communication. Effectively adapting to behaviors and practices and thereby earning legitimacy in the host country is easier when the foreign investors understand the local norms and beliefs. Thus, when normative distance is high, interaction with the local environment is particularly important, which will increase the importance of creating links with local partners (Ionascu, Meyer \& Estrin, 2004). Kazakhstan is a country with high ethnic and cultural diversity (Oleynik, 2002). Gaining legitimacy in such environment might be challenging for many foreign investors especially from normatively heterogeneous countries. This argument leads us to expect that to gain local legitimacy in a normatively distant country, foreign investors attempt to access local business partners. Hence, we hypothesize that:

Hypothesis 2: The greater the normative distance between the home and host country, the more likely the foreign investor will choose a JVover a WOS.

The World Bank has reported that every year more about $\$ 1$ trillion is paid in bribes (Dreher, Kotsogiannis \& McCorriston, 2007). Kazakhstan was ranked $122^{\text {nd }}$ out of 180 countries in the Corruption Perceptions Index 2017, so this is a serious concern (Transparency International,
2017).

Much of the research on country corruption and transparency shows that foreign investors from relatively less corrupt countries tend to seek a local partner to deal with more corrupt environments less known to them, to learn necessary skills, to obtain useful networks, and to reduce transaction costs related to corruption (El Said \& McDonald, 2002; Demirbag, Tatoglu \& Glaister, 2007; Estrin, Poukliakova \& Shapiro, 2009).

However, it can also be argued that foreign firms can also influence the local institutions, can follow their own rules of game, and be powerful bargainers that can refuse to easily adjust to the host country's environment, and follow their own rules of game (Chuck \& Tadesse, 2006; Ahlquist \& Prakash, 2009; Duanmu, 2011). Foreign investors from less corrupt countries may resist to adapt to the local institutional environment, and decide to enter into a foreign market alone making their own way because many foreign firms are concerned with the deterioration of their image, and potential costs (Duanmu, 2011). Usually foreign companies from relatively clean economic environments are more sensitive to the transparency level in local markets than those from more corrupt economies (Wu, 2006). Erramilli (1996) also found that a firm's decision-making, managerial beliefs, and attitudes are affected by its nation's institutional environment. Foreign firms with more transparent institutions are more likely to behave and operate similarly as in their home country. Firms may refuse to act with a local partner in way they view as inappropriate and may enter into the foreign market and operate alone. We expect that foreign investors from more transparent economies will choose a WOS over a JV. Hence the following hypothesis is suggested:

Hypothesis 3: The greater the transparency distance between the home and host country, the more likely the foreign investor will choose a WOS over a JV.

The significance of language in the studies of management has been stressed in the extant literature (Hofstede, 1980; Agar, 1994; West \& Graham, 2004; Luo \& Shenkar, 2006). Linguistic distances may affect cross-cultural communication and management decisions (Ronen \& Shenkar, 1985) and are critical to cultural or psychic distance between the home 
and host country (Demirbag, Tatoglu \& Glaister, 2007).

Linguistic distance is one of the keys to comprehending differences between home and host country environments (Nordstrom \& Vahlne, 1994) and may increase managers' perception of uncertainty in doing international business (Ronen \& Shenkar, 1985). Kazakhstan's unique linguistic space is characterized by sociolinguistic and demographic complexity. It is a bilingual country with Kazakh as the official language and Russian as interethnic language of communication. In addition, the use of these two languages differs by regions of the country. Depending on the location where the business operates, the linguistic distance from the home country can vary, increasing managers' perception of the level of risk of entering the country. When there is language difference, the foreign firms can resort to local partners to deal with uncertainty in communication and local operations. Linguistic distance influences ownership choice of foreign investors. In a complicated linguistic environment like Kazakhstan there is the need to cooperate with local partners. This leads to the following hypothesis formulation:

Hypothesis 4: The greater the linguistic distance between the home and host country, the more likely the foreign investor will choose a JVover a WOS.

Next, we focus on a significant political change that happened in Central Asian countries including Kazakhstan. In 2007, there was the establishment of the Eurasian Customs Union (ECU) and its members, which became Eurasian Economic Union in 2014, a more integrated bloc, include Armenia, Belarus, Kyrgyzstan, and Russia as well as Kazakhstan. Among them, Kazakhstan with a population of only 17 million is small in terms of the local market size, whereas the combined population of the ECU is now 180 million.

The enlarged market by regional economic integration is one of the main drivers for increased foreign investment and can alter entry mode strategies of foreign firms (Dalrymple, 2014). The market size and growth opportunities are important host country parameters affecting the entry mode choice. In general, in larger markets, foreign firms tend to opt for a WOS, because these markets are viewed as worth investing in and have larger sales potential (Kwon \& Konopa, 1993; Agarwal,
1994). The larger the size of the market, the greater the potential for growth and the higher the inclination of the firm to commit greater resources for its development. In smaller markets, firms tend to reduce their commitment and will go for a less risky equity-based entry mode or even non-equity entry modes. Root (1987) observed that in markets characterized by low sales potential, entry modes with lower resource commitment are favored by foreign investors. Hence, we can infer that a large market size leads to the modes of entry with more long-term resource commitment requiring higher level of investment, such as a WOS. Thus, we hypothesize:

Hypothesis 5: When the local market is regionally integrated, the more likely the foreign investor will choose a WOS over a JV.

World Investment Report by UNCTAD (2010) mentioned that FDI in land-locked developing economies are highly concentrated on the primary sector of a small number of resourcerich countries because of typically nondiversified production in those countries. According to Gomes-Casseres (1989), foreign investors are more likely to pursue equity-based ownership formations when they access locally controlled natural resources. Generally, natural resource intensive industries are often politically sensitive and foreign investors tend to seek local partners that may provide access to such delicate sectors (Hennart \& Larimo, 1998).

There is also a counter argument that natural resource-related industries in Kazakhstan are highly capital intensive and concentrated by foreign and local firms. Erramilli and D'Souza (1995) state that high FDI presence in natural resources often entails a significant amount of transaction-specific investments incurred by transaction costs. This has governance implications for foreign investors: In such cases firms need to establish a wholly-owned subsidiary that undertakes the transactionspecific investment rather that a joint venture, because local partners will try to avoid uncertainty due to such investment. Moreover, foreign firms need to secure control over as many of their local value chain activities as possible because each activity can influence the whole production and distribution process. Thus, in a natural resource-related industry it is more likely for foreign firms to prefer to set up a wholly owned subsidiary rather that a joint venture. Based on the argument above, we 
hypothesize that:

Hypothesis 6: When the foreign investor is in the natural resource-related industry, the more likely it will choose a WOS over a JV.

Foreign firms can differ in years of international experience and in experience in the target country market. Firms' international experience can be in operating modes including exporting, licensing, franchising, foreign direct investment, and strategic alliances with local firms. The extant literature shows that there is a preference for a WOS when the firm is more experienced internationally (Mutinelli \& Piscitello, 1998; Tseng \& Lee, 2010; Chiao, Lo \& Yu, 2010).

In the case of emerging markets where the risk of institutional failure and volatility is high, the host country experience is especially influential in entry mode choice (Khanna \& Palepu, 2000). Moreover, experience in the specific emerging market is more relevant than general international experience and plays a vital role for local operations. The greater the host country experience, the lower the need for cooperation with a local partner. and foreign companies with more experience and knowledge of the local environment will prefer a WOS to a JV. Much of the literature shows that foreign firms more likely operate by themselves when they have prior operating experience in the host country (Kogut \& Singh, 1988; GomesCasseres, 1989, Hennart, 1991; Andersson \& Svensson, 1994; Luo, 2001). Therefore, we expect the following hypothesis:

Hypothesis 7: The greater the host country experience of the foreign investor, the higher the probability that it will choose a WOS over a JV.

In general, foreign firms can have two different target markets: local and export markets. Firms' market orientation is broadly local market-oriented or export marketoriented. We expect that firms with different market orientations also differ in their choice of ownership mode in the foreign market. They have different opportunities available in the host country and specific resources to take advantage of their opportunities. Local marketoriented firms tend to focus on the market demands and market growth, and possess more resources like brand image, technical skills, and high quality (Luo \& Park, 2001). According to Erramilli (1996), local market-oriented firms are more interested in obtaining new consumers for their products in the host country and the reason why is that they tend to seek local partners to help them achieve this goal. Firms that have a lack of knowledge about local culture, local customers' preferences, and management style in the host country especially need partners for cooperation and assistance to attract new customers. Therefore, we expect that firms that are local market-oriented and consequently need to develop the host country market, tend to prefer partnership with a local company.

On the other hand, export-oriented investors concentrate on exporting to other countries (Pan \& Chi, 1999). Such investors are more interested in exploring advantages of the host country like available abundant natural resources, friendly investment environment, or low-cost labor (Sun, 1999; Luo \& Park, 2001). Also, they are more concerned with building effective manufacturing processes to make exporting operations (Kumar, 1994). Firms tend to choose an entry mode that enables greater control over manufacturing operations when exporting operations, which is a wholly-owned subsidiary. Taking into consideration the arguments above, we hypothesize that:

Hypothesis 8: The local market-oriented foreign investor is more likely to choose a JV while the export-oriented foreign investor is more likely to choose a WOS.

\section{METHODOLOGY AND DATA}

\section{Model Description}

Traditionally most empirical studies divide entry modes into dichotomous ones (Davidson \& McFetridge, 1985; Gatignon \& Anderson, 1988; Gomes-Casseres, 1989; Hennart, 1991; Kim \& Hwang, 1992; Agarwal \& Ramaswani, 1992). We focus on two types of categorical equity-based entry modes: a JV and a WOS. Accordingly, since the dependent variable in this study is dichotomous, a fitting statistical estimation technique is binomial logit regression analysis. The binomial logit model might be used when the dependent variable is binomial, when independent variables are qualitative and quantitative and when underlying assumptions of multivariate normality cannot be met (Norusis, 1994; Hair, Anderson, Tatham \& Black, 1995; Kaynak, Demirbag \& Tatoglu, 2007). The binomial logit model of this study can be expressed as: 
where $Y=\beta_{0}+\beta_{1} X_{1}+\beta_{2} X_{2}+\ldots+\beta_{n} X_{n}$

$\mathrm{X}_{1}=$ regulative distance, $\mathrm{X}_{2}=$ normative distance, $\mathrm{X}_{3}=$ transparency distance, $\mathrm{X}_{4}=$ linguistic distance, $\mathrm{X}_{5}=$ regional integration, $\mathrm{X}_{6}$ $=$ natural resource intensity of the target industry, $\mathrm{X}_{7}=$ host country experience of the firm, and $\mathrm{X}_{8}=$ market orientation of the firm.

\section{Sample}

In Kazakhstan, foreign equity ventures are recorded by a government agency, the Committee on Statistics of the Republic of Kazakhstan. From the original list we selected 102 foreign firms and then additional information on the selected firms was collected through the firm's official websites and other internet resources. The final database provides information on the name of the home country, the entry year, the proportion of foreign equity shareholding, the entry mode type, the sector of operation (main product/service), the year of starting activities in the host country, the year of divestment (if any) and the market orientation. The database consists of foreign firms established in Kazakhstan between 1992 and 2015 .

The study first focuses on the equity-based entry mode choice of foreign firms between full ownership (wholly owned subsidiary, both greenfield and acquisition) and sharing ownership with a local firm (joint venture, both greenfield and acquisition). Then, we examine the choice between a JV and a WOS. There are different criteria for classifying a JV and a WOS in the extant literature. As suggested by the previous research (Contractor, 1990; Franko, 1989; Kaynak, Demirbag \& Tatoglu, 2007), measuring the equity share distribution on a percentage continuum is not always appropriate. For instance, Pan (1996) proposes that a $1 \%$ difference in equity ownership holding the $23 \%$ and $24 \%$ equity ownership, holding $49 \%$ and $50 \%$, and holding $50 \%$ and $51 \%$, for example, have different strategic reasons and implications. In this study we define a JV as the case where the foreign equity ownership ranges from $10 \%$ to $90 \%$, because an investment of the foreign ownership less than $10 \%$ is a portfolio investment, not an FDI while a WOS is a case where the foreign equity ownership is more than $90 \%$.

Table 1. Characteristics of the Sample

\begin{tabular}{|l|l|c|c|}
\hline \multicolumn{1}{|c|}{ Item } & \multicolumn{1}{|c|}{ Classification } & $\mathrm{n}$ & $\%$ \\
\hline Type of entry mode & WOS (wholly-owned subsidiary) & 48 & 47.1 \\
& JV (joint venture) & 54 & 52.9 \\
\hline Year of entry & $1992-2006$ & 61 & 59.8 \\
& $2007-2015$ & 41 & 40.2 \\
\hline Home country region & EU & 36 & 35.3 \\
& Post-Communist countries & 13 & 12.7 \\
& USA/Canada & 14 & 13.7 \\
& Northeastern Asia & 33 & 32.4 \\
& South Asia and Middle East & 6 & 5.9 \\
\hline Sector of operation & Mining, petroleum and gas & 35 & 34.3 \\
& Metal, iron and steel & 28 & 27.5 \\
& Other manufacturing & 16 & 15.7 \\
& Construction and logistics & 9 & 8.8 \\
& Petroleum and gas services & 7 & 6.9 \\
& Other services & 7 & 6.9 \\
\hline Total & & 102 & 100.0 \\
\hline
\end{tabular}


Table 1 describes main characteristics of the sample firms along key items. The distribution of ownership is as follows: 48 firms (47.1\% of the total) by a WOS, and $54(52.9 \%)$ by a JV. The average foreign equity ownership is $71.7 \%$. In terms of the investors' home country 36 (35.3\%) are from the EU, 13 (12.7\%) from PostCommunist countries, 14 (13.7\%) from North America, and 33 (32.4\%) from Northeastern Asia. Sample firms' industries are as follows: mining, petroleum and gas occupy $34.3 \%$, metal, iron and steel, $27.5 \%$, other manufacturing, $15.7 \%$, and services, $22.5 \%$.

\section{MEASURES OF VARIABLES \\ Dependent variables}

In this study binomial logistic regression was applied to test the hypotheses. We used the binary dependent variable: firms with a foreign ownership between $90 \%$ and $100 \%$ correspond to 1 , a WOS and 0 , a JV as shown as below. The data used to construct this variable referred to the ownership structure at the time a firm was initially set up.

MODE $=0$ if the firm has established a joint venture (JV),

$=1$ if the firm has established a wholly owned subsidiary (WOS).

\section{Independent variables}

Regulative distance. The regulative distance is measured by the Economic Freedom Index published by the Heritage Foundation (Estrin, Jan, Evzen \& Jan, 2007). We used the data of the Economic Freedom Index published in 2014. There are ten different indices in the index, ranging from a minimum of 0 (repressed) and a maximum of 100 (free). Six indices of them are particularly relevant to regulative distance and show how they pertain to foreign direct investment, namely: Regulatory Efficiency (Business Freedom, Labor Freedom), Rule of Law (Property Rights, Freedom from Corruption), Open Markets (Trade Freedom, Investment Freedom). The variable is computed as the absolute difference between the average scores of Kazakhstan and those scores of the accordant home country (Estrin, et al., 2007). Today Kazakhstan ranks $41^{\text {st }}$ and belongs to the group of the Moderately Free Economies.

Normative distance. The normative distance has been calculated using four dimensions of Hofstede's culture index, which represent the normative pillar of a country's institutional profile. These dimensions are power distance index, individualism vs. collectivism index, masculinity vs. femininity index, and uncertainty avoidance index. An extensive literature shows the relevance of distance in Hofstede's cultural construct for the entry mode decision (Kogut \& Singh, 1988; Barkema \& Vermeulen, 1998; Chang \& Rosenzweig, 2001).

Having examined the effects of four measures of cultural distance on the foreign investor's establishment mode choice, we selected the traditional Kogut and Singh (1988) index, which uses the differences in the scores on Hofstede's (1980) dimensions of national culture between the host country, in this case Kazakhstan and the foreign investor's home country. These differences are corrected for differences in the variance of each dimension and then arithmetically averaged. This can be algebraically written as follows:

$$
\mathrm{ND}=\sum_{\mathrm{i}=1}^{4}\left\{\left(\mathrm{I}_{\mathrm{ij}}-\mathrm{I}_{\mathrm{ik}}\right)^{2} / \mathrm{V}_{\mathrm{i}}\right\} / 4
$$

where ND is the normative distance between country $\mathrm{j}$ and Kazakhstan, $\mathrm{I}_{\mathrm{ij}}$ is country j's score on the ith cultural dimension, $\mathrm{I}_{\mathrm{ik}}$ is the score of Kazakhstan on this dimension, and $V_{i}$ is the variance of the score of the dimension.

Transparency distance. As a transparency distance measure, we chose the corruption index from Corruption Perception Index (CPI) 2014 for its extensive country and period coverage (Tekin-Koru, 2006). The CPI generally defines corruption as "the misuse of public power for private benefit." The index is composed in a way that high scores indicate low corruption level in the country. The CPI currently ranks 180 countries on a scale from 100 (very clean) to 0 (highly corrupt). The distance is computed as the absolute difference between the home country and Kazakhstan. Kazakhstan ranked $133^{\text {rd }}$ in 2016 with a score of 29 and $122^{\text {nd }}$ in 2017 with 31, improving its position in some degree.

Linguistic distance. Linguistic distances between languages are commonly computed by counting shared branches in language-familytrees (Guiso, Sapienza \& Zingales, 2009). This language-tree approach deals with strong cardinality assumptions and arbitrarily chosen parameters. We indicated value 1 for languages in the same language-family tree with Kazakh (official language) and Russian (commonly used in Kazakhstan), and 0 otherwise. 
Regional integration. We measure the regional integration variable as a dummy variable by dividing foreign firms into two: Firms with value 0 that entered the market before 2007 (when the treaty of Eurasian Customs Union was signed), and those with value 1 , after it.

Natural resource intensity. For the variable of natural resource intensity of the foreign investor's target industry, the value of 1 is given when the subsidiary is in a resource-intensive industry and 0 otherwise. We identify resourceintensive industries as follows: metal, iron and steel; mining, petroleum and gas; forestry, agricultural, fisheries industries; textiles
(Gomes-Casseres, 1989).

Host country experience. For the variable of host country experience of the firm, we used absolute difference between entering year of the Kazakhstani market through ownership-based equity mode and year of starting operations in the market. Hence it was proxied by the total count years since the first investment made by the parent firm in Kazakhstan. Earlier studies such as Hennart and Park (1993), Padmanabhan and Cho (1999), Larimo (2003), and Arslan and Larimo (2011) also used such similar operationalization.

Table 2. Variables and Measures

\begin{tabular}{|l|l|}
\hline \multicolumn{1}{|c|}{ Variables } & \multicolumn{1}{|c|}{ Measures and Sources } \\
\hline Regulative distance & $\begin{array}{l}\text { The distance in rules and regulations between the home and host } \\
\text { countries, the 'Regulatory Factor' of the Economic Freedom Index } \\
\text { published by the Heritage Foundation. }\end{array}$ \\
\hline Normative distance & $\begin{array}{l}\text { Cultural distance index between the home and host countries (CDI), based } \\
\text { on Hofstede's cultural dimensions. }\end{array}$ \\
\hline $\begin{array}{l}\text { Transparency } \\
\text { distance }\end{array}$ & $\begin{array}{l}\text { Transparency distance between the home and host countries. Corruption } \\
\text { Perception Index 2014. }\end{array}$ \\
\hline Linguistic distance & $\begin{array}{l}\text { Linguistic distance between the home and host countries, according to } \\
\text { language family tree. }\end{array}$ \\
\hline Regional integration & Year of establishing Eurasian Customs Union (2007), before and after it. \\
\hline $\begin{array}{l}\text { Natural resource } \\
\text { intensity }\end{array}$ & $\begin{array}{l}\text { Target industry. Resource-intensive industries were identified as metal, } \\
\text { iron and steel; mining, petroleum and gas; forestry, agricultural, fisheries } \\
\text { industries; textiles. }\end{array}$ \\
\hline $\begin{array}{l}\text { Host country } \\
\text { experience }\end{array}$ & $\begin{array}{l}\text { Years of presence in Kazakhstan (Years of presence that foreign investor } \\
\text { has had in the host market before the subsidiary is established). }\end{array}$ \\
\hline Market orientation & $\begin{array}{l}\text { Export-oriented vs. local market-oriented. Market orientation of the } \\
\text { subsidiary, the ratio of products on export and local market. }\end{array}$ \\
\hline
\end{tabular}

The correlation matrix of the variables is shown in Table 3. Since all variables show correlation lower than 0.7 , no severe correlation is indicated (Anderson, Sweeney, Williams, Camm \& Cochran, 2016). Moreover, we could further confirm that there is no serious multicollinearity problem, since VIF (variance inflation factor) coefficients for all variables are lower than 10 (Allison, 1999).

Market orientation. Since this study focuses on the distinction between export orientation and local market orientation, the percentage of export from total sales is used to measure the firm's market orientation as in previous studies (Kumar, 1994; Luo \& Park, 2001; Pan \& Chi, 1999). Foreign firms with an export percentage of $50 \%$ or below are perceived as local marketoriented are coded 0 , and export-oriented coded 1 , otherwise. 
Table 3. Correlation Matrix of Variables

\begin{tabular}{|l|l|l|l|l|l|l|l|l|l|l|}
\hline & 1 & 2 & 3 & 4 & 5 & 6 & 7 & 8 & 9 & VIF \\
\hline Entry mode & 1.000 & & & & & & & & & \\
\hline $\begin{array}{l}\text { Regulative } \\
\text { distance }\end{array}$ & -0.024 & 1.000 & & & & & & & & \\
\hline $\begin{array}{l}\text { Normative } \\
\text { distance }\end{array}$ & -0.122 & $0.395^{* *}$ & 1.000 & & & & & & & \\
\hline $\begin{array}{l}\text { Transparency } \\
\text { distance }\end{array}$ & 0.109 & -0.217 & $0.569^{* *}$ & 1.000 & & & & & & 1.2938 \\
\hline $\begin{array}{l}\text { Linguistic } \\
\text { distance }\end{array}$ & 0.053 & -0.040 & $-0.553^{* *}$ & $-0.539^{* *}$ & 1.000 & & & & & 1.827 \\
\hline $\begin{array}{l}\text { Regional } \\
\text { integration }\end{array}$ & $-0.028^{*}$ & -0.050 & -0.087 & -0.014 & 0.151 & 1.000 & & & & 1.312 \\
\hline $\begin{array}{l}\text { Natural } \\
\text { ressource } \\
\text { intensity }\end{array}$ & $-0.458^{* *}$ & 0.169 & 0.192 & -0.025 & -0.019 & 0.098 & 1.000 & & & 1.848 \\
\hline $\begin{array}{l}\text { Host country } \\
\text { experience }\end{array}$ & -0.051 & 0.018 & -0.106 & $-0.291^{* *}$ & $0.228^{*}$ & -0.129 & $0.260^{* *}$ & 1.000 & & 1.480 \\
\hline $\begin{array}{l}\text { Market } \\
\text { orientation }\end{array}$ & $-0.331^{* *}$ & $0.203^{*}$ & $0.314^{* *}$ & 0.022 & 0.158 & 0.168 & $0.667 *$ & $0.304^{* *}$ & 1.000 & 2.062 \\
\hline
\end{tabular}

Note: ${ }^{* *} \mathrm{p}<0.05 ;{ }^{*} \mathrm{p}<0.1$ (2-tailed)

\section{RESULTS AND DISCUSSION}

The hypotheses were tested by binomial logit regressions on the hypothesized relationships between the variables and foreign firms' ownership choices between full equity ownership (a WOS) and shared equity ownership (a JV). An estimated positive coefficient for an independent variable refers to foreign firms' preference for a WOS over a JV, while a negative one indicates the opposite.

Table 4 shows the overall fit of the model. The $\chi^{2}(1.420, \mathrm{df}=8, \mathrm{p}<0.01)$ statistic indicates the rejection of the null hypothesis that all the estimated coefficients equate with 0 , showing a high fit with the model. The - 2 Log Likelihood statistic turned out to be 109.63 and the pseudo $\mathrm{R}^{2}, 0.36$, both also revealing that the model's explanatory power is normal.

The results of the coefficient estimation are presented in Table 5. Among the variables empirically supported is the TRANSPARENCY DISTANCE variable (Hypothesis 3) that equitybased entry mode decision of foreign investors in Kazakhstan is affected by the distance between the transparency levels of the host and home countries. The relationship was shown to be positive and weakly significant at the 0.1 level. Hence this finding indicates that for institutional theory the greater the transparency distance between the home and host countries, the more likely foreign investors will choose a WOS than a JV. It confirms Wu's (2006) argument that MNEs from transparent home countries prefer WOSs more than those from corrupt countries do.

The REGIONAL INTEGRATION variable (Hypothesis 5) also turned out to be positive and significant at the 0.1 level, suggesting that foreign firms entering after establishment of Eurasian Customs Union tend to choose a WOS over a JV. The extant literature argues that in larger markets foreign firms opt for a WOS, because these markets are expected as worth investing and have a larger potential for high sales (Kwon \& Konopa, 1993; Agarwal, 1994; Trevino \& Mixon, 2004). Hence it affirms our proposition that this regional trade agreement impacts entry mode strategy of foreign investors in Kazakhstan.

Further, the results on NATURAL RESOURCE 
INTENSITY (Hypothesis 6) are found to be positive and strongly supported at the 0.01 level, meaning that the industry characteristic related to natural resources of the host country has a high explanatory power of ownership structure decision of firms. It was shown that foreign investors entering Kazakhstan are more likely to prefer a WOS to a JV when investing in a resource intensive industry. This finding contradicts the results of previous studies (Gomes-Casseres, 1989; Cleeve, 1997; Hennart \& Larimo, 1998) arguing that such industries are often politically sensitive, and that a local partner can provide the foreign investor help with securing permits. Our empirical results echo Luo's (2001) assertion that the growth in the number of firms in a natural resource intensive industry increases their preference for WOSs to JVs.

Hypothesis 7 is also confirmed because the coefficient for HOST COUNTRY EXPERIENCE is positive and significant at the 0.1 level, indicating that foreign investors are more likely to choose not to share the control with partners and to prefer a WOS. The host country experience of foreign investors influences the entry mode decision by helping them reduce the uncertainties due to the unstable host country environment. This finding also supports the results from the extant literature that host country experience leads to the less likelihood that foreign firms with prior operating experience in the host country prefer a cooperative mode of entry (Kogut \& Singh, 1988; Gomes-Casseres, 1989, 1990; Erramilli, 1991; Hennart, 1991; Cleeve, 1997; Barbosa, Guimaraes \& Woodward, 1998; Andersson \& Svensson, 1994; Luo, 2001).

Table 4. Omnibus tests of model coefficients

\begin{tabular}{|l|c|r|c|}
\hline & $\chi^{2}$ & df & Sig. \\
\hline Step & 31.420 & 8 & 0.000 \\
\hline Block & 31.420 & 8 & 0.000 \\
\hline Model & 31.420 & 8 & 0.000 \\
\hline
\end{tabular}

Notes: Estimation terminated at iteration number 4 because parameter estimates changed by less than .001
Table 5. Results of binomial logit regression

\begin{tabular}{|l|r|r|}
\hline \multicolumn{1}{|c|}{ Variable } & Coefficient & $\begin{array}{r}\text { Wald } \\
\text { statistics }\end{array}$ \\
\hline Regulative distance & 0.039 & 0.366 \\
\hline Normative distance & -0.022 & 1.747 \\
\hline $\begin{array}{l}\text { Transparency } \\
\text { distance }\end{array}$ & $0.031^{*}$ & 3.423 \\
\hline Linguistic distance & -0.016 & 0.000 \\
\hline Regional integration & $1.064^{*}$ & 3.403 \\
\hline Natural resources & $2.294^{* * *}$ & 10.542 \\
\hline $\begin{array}{l}\text { Host country } \\
\text { experience }\end{array}$ & $0.111^{*}$ & 3.590 \\
\hline Market orientation & 0.225 & 0.118 \\
\hline Model Chi-square & 31.420 & \\
\hline Correct Ratio & 73.5 & \\
\hline Cox \& Snell R & 0.265 & \\
\hline Nagelkerke $\mathrm{R}^{2}$ & 0.354 & \\
\hline
\end{tabular}

Notes: ${ }^{* * *} \mathrm{p}<0.01 ;{ }^{* *} \mathrm{p}<0.05 ;{ }^{*} \mathrm{p}<0.1$

For the remaining variables, however, no empirical support was found. For Hypothesis 1 on REGULATIVE DISTANCE between the home and host country, the coefficient of the variable was not significant, indicating that the foreign firms' ownership-based entry mode choice is not related to regulative distance between the home and host countries. We do not find any support for Hypothesis 2 either that the higher the NORMATIVE DISTANCE is, the more likely a foreign firm will choose shared ownership. Our results also do not support Hypothesis 4, confirming that there is no empirical evidence that LINGUISTIC DISTANCE influences the choice of foreign investors in terms of ownership structure. Lastly, Hypothesis 8 is not supported empirically either, indicating that there is no relationship among foreign firms' choice of ownership level and their MARKET ORIENTATION.

\section{CONCLUSION}

Test results on the factors affecting choice of equity-based entry modes by foreign firms in Kazakhstan show empirical support for the variables including transparency distance, regional integration, natural resource and host 
country experience. Transparency distance results show that unlike most existing studies, firms from less corrupt countries prefer a WOS to a JV. This result confirms the argument that a relatively high corruption level in Kazakhstan plays a critical role in decision-making of foreign investors.

We found that the Eurasian Customs Union, a regional integration body in Central Asia influences the choice of ownership level, confirming that firms entering after its establishment in 2007 tend to prefer a WOS. It is also shown that host country experience has effects on entry strategy of foreign investors: For foreign firms that have some experience in the host country it is easier to conduct business in a transition environment in comparison to investors without experience, and therefore foreign firms that are experienced choose full ownership over part ownership. This result echoes the extant literature, showing that host country experience directly influences entry mode strategy of foreign firms by enabling firms to reduce uncertainties related to the environmental instability. More interestingly foreign investors in Kazakhstan opt to establish a WOS rather than a JV when their operating industry requires natural resources. In general, these results go in line with corresponding theoretical propositions, but contradictory with some earlier findings in the literature.

To summarize, an important contribution of this study is to attempt to examine the ownership structure strategies of foreign investors in an understudied transition economy - Kazakhstan. Kazakhstan and other Central Asian countries still remain less examined in the international business literature.

\section{Limitations of the Study}

The main limitation of this study lies in the small sample size, since only 102 firms were used for empirical analysis. A larger sample would enhance the validity of the study. Further this study did not include other firm-level variables such as technological intensity, international operationalization level, parent firm size, product differentiation and others. This is mainly due to data limitations, especially in the case of foreign firms from different home countries. Moreover, focusing on just equitybased entry mode choices may limit the comprehensive understanding in the entry mode choice of foreign firms in Kazakhstan.

Another limitation is that factors other than those we studied can affect the entry mode choice for initial and subsequent entries into a foreign country (Chang \& Rosenzweig, 2001). Further research may analyze how the effects of additional determinants on entry mode choice vary for subsequent entries. Finally, our study is limited by the geographical scope. It considers the factors of influencing foreign investors' entry strategy in a single country Kazakhstan. Further work is needed to find out how much further our findings might be generalized to other transition or non-transition countries.

\section{Further Study}

This study can be extended in several directions. First, research analyzing changes happening over time in ownership patterns would enhance our understanding of the impact of institutional changes on equity mode choice in entering foreign countries. Second, the institutional distance measures used in this study could be replicated in other contexts involving foreign firms from various transition countries, which would serve to further validate the findings of this study. Third, there may be additional country- and firm-level determinants to be considered in future studies. Among them are included political stability, political regimes, technological intensity, internationalization level, firm size, product differentiation, cognitive distance and other institutional determinants. Finally, comparison studies on countries with a development level like that of Kazakhstan and diverse culture dimensions would provide a deeper insight into the role of the institutional environment and firm level factors on foreign investors' choice of entry mode.

\section{Managerial and Policy Implications}

The results of our study show that foreign investors' selection of WOSs over JVs was affected by factors such as regional integration, the type of industry, international experience and, among institutional variables, transparency distance rather than regulative, normative and linguistic distance. All these factors are concerned with the necessity of foreign investors' control of local operation, implying that foreign firms entering the country may 
need to establish WOSs, securing control of the operation in the local environment that they perceived as characterized by such features. For local firms seeking joint ventures with foreign firms, this point also may be worth considering.

The policy implications of this study mostly apply to the Kazakhstani government and government of countries with similar historical and economic backgrounds such as other PostCommunist transitional economies interested in attracting more foreign direct investment. Our findings show that transparency distance, the establishment of a regional trade bloc including the host country such as the Eurasian Customs Union, the natural resource intensity of the target industry, and host country experience of foreign investors influence equity-based entry strategy of foreign firms. This study might be of special interest to members of ECU agreement, such as Armenia, Belarus, Kyrgyzstan, Russia, and other prospective members. Regional integration is a relatively new determinant in entry mode choice studies. In this sense it is meaningful that regional trade integration plays a significant role in foreign investors' decision on entry mode choice in Post-Communist transition economies with a relatively small local market like Kazakhstan.

The significant level of transparency distance can be a signal for highly corrupted transition countries. The results show that foreign firms entering a country with greater transparency distance prefer to set up a WOS instead of joining partnership, which might have a negative impact on diversification of the Kazakhstani economy and industry. The government needs to encourage the partnership with foreign firms to access their technological know-how, managerial skills, and efficient production abilities. To create favorable environment for FDI and promote more involvement of foreign investors in partnership relationships with local firms, there is the need to improve the transparency environment.

\section{ACKNOWLEDGEMENT}

This paper was supported by the 2018 research fund of Hankuk University of Foreign Studies.

\section{BIBLIOGRAPHY}

Agar, M. (1994). Language Shock, Understanding the Culture of Conversation. New York:
Quill.

Agarwal, S. (1994). Socio-cultural distance and the choice of joint ventures: A contingency perspective. Journal of International Marketing, 2(2), 63-80.

Agarwal, S. and Ramaswani, S. N. (1992). Choice of foreign market entry mode: impact of ownership, location and internalization factors. Journal of International Business Studies, 23, 1-27.

Ahlquist, J. and Prakash, A. (2009). FDI and the cost of contract enforcement in developing countries. Policy Sciences, 43, 181-200.

Allison, P. D. (1999). Multiple Regression: A primer. Thousand Oaks, CA: Pine Forge Press.

Anderson, E. and Gatignon, H. (1986). Modes of foreign entry: A Transaction cost analysis and propositions. Journal of International Business Studies, 173), 1-26.

Anderson, D. R., Sweeney, D. J., Williams, T. A., Camm, J. D. and Cochran, J. J. (2016). Statistics for Business and Economics, $13^{\text {th }}$ edition. Boston, MA: Cengage Learning.

Andersson, T. and Svensson, R. (1994). Entry modes for direct investment determined by the composition of firm-specific skills. Scandinavian Journal of Economics, 96, 551560.

Antal-Mokos, Z. (1998). Privatization, Politics, and Economic Performance in Hungary. Cambridge, UK: CUP.

Arslan, A. and Larimo, J. (2011). Greenfield investments or acquisitions: Impacts of institutional distance on establishment mode choice of multinational enterprises in emerging economies. Journal of Global Marketing, 24(4), 345-356.

Aulakh, P. S. and Kotabe, M. (1997). Antecedents and performance of channel integration in foreign markets. Journal of International Business Studies, 28, 145-175.

Baigabylova, N. (2012). Internationalization of Production in Kazakhstan and its Economic Implications: The Role of Foreign Investment and Transnational Corporations. Department of Economic History. Lund University.

Barbosa, N., Guimaraes, P. and Woodward, D. (1998). Foreign firm entry in Portugal: An application of event count models. $25^{\text {th }}$ Annual EARIE Conference, Copenhagen, 
Denmark.

Barkema, H. G. and Vermeulen, F. (1998). International expansion through start-up or acquisition: A learning perspective. Academy of Management Journal, 41(1), 726.

Beugelsdijk, S., Kostova and Roth, K. (2017). An overview of Hofstede-inspired country-level culture research in international business since 2006. Journal of International Business Studies, 48, 30-47.

Boyacigiller, N. A., Goodman, R. A. and Phillips, M. E. (2004). Crossing Cultures: Insights from Master Teachers. New York, NY: Routledge.

Brouthers, K. D. (2002). Institutional, cultural and transaction cost influences on entry mode choice and performance. Journal of International Business Studies, 33(2), 203221.

Canabal, A. and White III, G.O. (2008). Entry mode research: Past and future. International Business Review, 173): 267284.

Chang, S. J. and Rosenzweig, P. M. (2001). The choice of entry mode in sequential foreign direct investment. Strategic Management Journal, 22(8), 747-776.

Chiao, Y. C., Lo, F. Y. and Yu, C. M. (2010). Choosing between wholly-owned subsidiaries and joint ventures of MNCs from an emerging market. International Marketing Review, 273), 338-365.

Chuck, K. and Tadesse, S. (2006). The MNC as an agent of change for host-country institutions: FDI and corruption. Journal of International Business Studies, 376), 767785.

Cleeve, E. (1997). The motives for joint ventures: A transaction costs analysis of Japanese MNEs in the UK. Scottish Journal of Political Economy, 44(1), 31-43.

Contractor, F. J. (1990). Ownership patterns for U.S. joint ventures abroad and the liberalization of foreign government regulations in the 1980s: Evidence from the benchmark surveys. Journal of International Business Studies, 21(1), 55-73.

Coase, R. H. (1937). The nature of the firm. Economica, 4(16): 386-405.

Contractor, F. J. (2001). Foreign market entry strategies. In R. L. Tung (Ed). The IEBM
Handbook of International Business, 141163. London, UK: Thomson Learning.

Dalrymple, R. (2014). The impact of the Eurasian Customs Union on foreign direct investment in Kazakhstan. MA Thesis, University of Washington.

Davidson, W. H. and McFetridge, D. G. (1985). Key characteristics in the choice of international technology transfer mode. Journal of International Business Studies, 16(2), 5-21.

Davis, P. S., Desai, A. B. and Francis, J. D. (2000). Mode of international entry: An isomorphism perspective. Journal of International Business Studies, 31, 239-258.

Delios, A. and Beamish, P. W. (1999). Ownership strategy of Japanese firms: Transactional, institutional, and experience influences. Strategic Management Journal, 20, 915-933.

Demirbag, M., Tatoglu, E. and Glaister, K. W. (2007). Dimensions of European direct investment activity in Turkey: Patterns and prospects. International Journal of Emerging Markets, 2(3), 274-297.

Dikova, D. and Witteloostuijn, A. (2005). Acquisition versus greenfield foreign entry: Diversification mode choice in Central and Eastern Europe. University of Groningen Working Paper.

Dikova, D. and Witteloostuijn, A. (2007). Foreign direct investment mode choice: Entry and establishment modes in transition economies. Journal of International Business Studies, 38(6), 1013-1033.

Dreher, A., Kotsogiannis, C. and McCorriston, S. (2007). Corruption around the world: Evidence from a structural model. Journal of Comparative Economics, 35(3), 443-466.

Duanmu, J. L. (2011). The effect of corruption distance and market orientation on the ownership choice of MNEs: Evidence from China. Journal of International Management, 172), 162-174.

El Said, H. and McDonald, F. (2002). Institutional reform and entry mode by foreign firms: The case of Jordan. Journal for Institutional Innovation, Development and Transition, 6 , 76-88.

Ericson, R. E. (1991). The classical Soviet-type economy: Nature of the system and implications for reform. Journal of Economic Perspectives, 5(4), 11-27. 
Erramilli M. K. and D'Souza, D. E. (1995). Uncertainty and foreign direct investment: The role of moderators. International Marketing Review, 12(3), 47-60.

Erramilli, M. K. (1996). Nationality and subsidiary ownership patterns in multinational corporations, Journal of International Business Studies, 272), 225248.

Erramilli, M. K. (1990). Entry mode choice in service industries. International Marketing Review, 75), 50-62.

Estrin, S., Jan, H., Evzen, K. and Jan, S. (2007). Effects of privatization and ownership in transition economies. International Policy Center Working Paper, 30. University of Michigan.

Estrin, S., Poukliakova, S. and Shapiro, D. (2009). The performance effects of business groups in Russia. Journal of Management Studies, 46(2), 393-420

Franko, L. G. (1989). Use of minority and 50-50 joint ventures by United States multinationals during the 1970s: The interaction of host country policies and corporate strategies. Journal of International Business Studies, 2011), 19-40.

Gatignon, H. and Anderson, E. (1988). The multinational corporation's degree of control over foreign subsidiaries: An empirical test of a transaction cost explanation. Journal of Law, Economics, and Organization, 4(2), 305-336.

Gomes-Casseres, B. (1989). Ownership structures of foreign subsidiaries: Theory and evidence. Journal of Economic Behavior and Organization, 11(1), 1-25.

Gomes-Casseres, B. (1990). Firm ownership preferences and host government restrictions: An integrated approach. Journal of International Business Studies, 21(1), 122.

Guiso, L., Sapienza, L. and Zingales, L. (2009). Cultural biases in economic exchange? Quarterly Journal of Economics, 124(3), 1095-1131.

Hair, J. F., Anderson, R. E., Tatham, R. L. and Black, W. C. (1995). Multivariate Data Analysis, $4^{\text {th }}$ edition. Englewood Cliffs, NJ: Prentice Hall.

Hennart, J. F. (1991). A Transaction costs theory of equity joint ventures: An empirical study of Japanese subsidiaries in the United States. Management Science, 37(4), 483-497.

Hennart, J. F. and Larimo, J. (1998). The impact of culture on the strategy of multinational enterprises: Does national origin affect ownership decisions?. Journal of International Business Studies, 29(3), 515538.

Hennart, J.-F. and Park, Y. R. (1993). Greenfield vs. acquisition: The strategy of Japanese investors in the United States. Management Science, 39, 1054-1070.

Hennart, J. -F. and Slangen, A. H. L. (2015). Yes, we really do need more entry mode studies! A commentary on Shaver. Journal of International Business Studies, 46(1): 114122.

Hofstede, G. H. (1980). Culture's Consequences: International Differences in Work-related Values. Thousand Oaks, CA: Sage.

Hollender, L., Zapkau, F.B. and Schwens, C. (2017). SME foreign market entry mode choice and foreign venture performance: The moderating effect of international experience and product adaptation. International Business Review, 26(2), 250263.

Ionascu, D., Meyer, K. E. and Estrin, S. (2004). Institutional distance and international business strategies in emerging economies. William Davidson Institute Working Paper 728. University of Michigan.

Kaynak, E., Demirbag, M., and Tatoglu, E. (2007). Determinants of ownership-based entry mode choice of MNEs: Evidence from Mongolia. Management International Review, 474), 505-530.

Khanna, T. and Palepu, K. (2000). The future of business groups in emerging markets: Longrun evidence from Chile. Academy of Management Journal, 43(3), 268-285.

Kim, W. C. and Hwang, P. (1992). Global strategy and multinationals' entry mode choice. Journal of International Business Studies, 23(1), 29-54.

Kogut, B. and Singh, H. (1988). The effect of national culture on the choice of entry mode. Journal of International Business Studies, 19(3), 411-432.

Kornai, J. (1992). The Socialist System: The Political Economy of Communism. Princeton, NJ: Princeton University Press. 
Kumar, N. (1994). Determinants of export orientation of foreign production by U.S. multinationals: An intercountry analysis. Journal of International Business Studies, 25(1), 141-156.

Kwon, Y. C. and Konopa, L. J. (1993). Impact of host country market characteristics on the choice of foreign market entry mode. International Marketing Review,101), 6076.

Lagutina M. (2018). The Eurasian Economic Union in the context of transformation of the international trade system. Globalization and Trade Integration in Developing Countries, 21.

Larimo, J. (2003). Form of investment by Nordic Firms in world markets. Journal of Business Research, 56(10), 791-803.

Lu, J. W. (2002). Intra- and inter-organizational imitative behavior: Institutional influences on Japanese firms' entry mode choice. Journal of International Business, 33(1), 1937.

Luo, Y. (2001). Determinants of entry in an emerging economy: A multilevel approach. Journal of Management Studies, 38(3), 443472.

Luo, Y. and Park, S. H. (2001). Strategic alignment and performance of marketseeking MNCs in China. Strategic Management Journal, 22(2), 141-155.

Luo, Y. and Shenkar, O. (2006). The multinational corporation as a multilingual community: Language and organization in a global context. Journal of International Business Studies, 373): 321-339.

Meyer, K. E. (2001). The institutions, transaction costs, and entry mode choice in Eastern Europe. Journal of International Business, 32(2), 357-367

Mutinelli, M. and Piscitello, L. (1998). The influence of firm's size and international experience on the ownership structure of Italian FDI in manufacturing. Small Business Economics, 11(1), 43-56.

Nordstrom, K. and Vahlne, J. E. (1994). Is the globe shrinking? Psychic distance and the establishment of Swedish sales subsidiaries during the last 100 years. In M. Landeck (Ed.), International Trade: Regional and Global issues: 41-56. New York, NY: St. Martin's Press.
Norusis, M. J. (1994). SPSS Advanced Statistics 6.1. Chicago, IL.: SPSS Inc.

Oleynik, I. S. (2002). Kazakhstan: Country Study Guide. Washington, DC: International Business Publications.

Oxley, J. E. (1999). Institutional environment and the mechanisms of governance: The impact of intellectual property protection on the structure of inter-firm alliances. Journal of Economic Behavior and Organization, 38, 283-309.

Padmanabhan, P. and Cho, K. R. (1999). Decision specific experience in foreign ownership and establishment strategies: Evidence from Japanese firms. Journal of International Business Studies, 301), 25-44.

Pan, Y. (1996). Influences on foreign equity ownership level in joint ventures in China. Journal of International Business Studies, 271), 1-26.

Pan, Y. and Chi, P. S. K. (1999). Financial performance and survival of multinational corporations in China. Strategic Management Journal, 2044), 359-374.

Peng, M. W. (1994). Organizational changes in planned economies in transition: An eclectic model. Advances in International Comparative Management, 9, 223-251.

Peng, M. W. (2009). Global Strategy. Singapore: South Western Cengage Learning.

Ronen, S. and Shenkar, O. (1985). Clustering countries on attitudinal dimensions: A review and synthesis. Academy of Management Review, 10(3), 435-454.

Root, F. R. (1987). Entry Strategies for International Markets. Lexington, MA: D. C. Heath.

Sartor, M.A. and Beamish P.M. (2018). Host market government corruption and the equity-based foreign entry strategies of multinational enterprises. Journal of International Business Studies, 49, 346-370.

Scott, W. R. (2008). Crafting analytic framework I: Three pillars of institutions in Institutions and organizations, 3rd edition, Ch.3: 47-71. Los Angeles, CA: Sage.

Shaver, J. M. (2013). Do we really need more entry mode studies? Journal of International Business Studies, 44(1): 23-27.

Slangen, A. H. L. and van Tulder, R. J. M. (2009). Cultural distance, political risk, or governance quality? Towards a more 
accurate conceptualization and measurement of external uncertainty in foreign entry mode research. International Business Review, 18, 276-291.

Sun, H. (1999). FDI, foreign trade and transfer pricing. Journal of Contemporary Asia, 29(3), 362-382.

Swaan, W. (1997). Knowledge, Transaction Costs and the Creation of Markets in Post-Socialist Economies. Vol. II. London and New York: Routledge.

Tekin-Koru, A. (2006). Corruption and the ownership composition of the multinational firm at the time of entry: evidence from Turkey. Journal of Economics and Finance, 30(2), 251-269.

Thornton, J. and Mikheeva, N. N. (1996). The strategies of foreign and foreign-assisted firms in the Russian Far East: Alternatives to missing infrastructure. Comparative Economic Studies, 38(4), 85-120.

Trevino, L. J. and Mixon, F. G. (2004). Strategic factors affecting foreign direct investment decisions by multinational enterprises in Latin America. Journal of World Business, 39(2), 233-243.

Transparency International (2017). Transparency index, Retrieved July 1, 2018 from https://www.transparency.org/news/feature /corruption_perceptions_index_ 2017\#table.

Tseng, C. H. and Lee, R. P. (2010). Host environmental uncertainty and equity-based entry mode dilemma: The role of market linking capability. International Business Review, 19, 407-418.

Tugut, M. and Lee, C. Y. (2007). Doing business in Kazakhstan: Opportunities, challenges, and suggestions. The Journal of Global Business Management, 3(1), 109-119.

United Nations Conference on Trade and Development (UNCTAD). (various issues). World Investment Report. New York and Geneva: United Nations.

Vakulchuk, R. and Overland, I. (2018). Kazakhstan: Civil Society and Natural Resource Policy in Kazakhstan. Oslo, Norway, 143-144.

Werner, S. (2002). Recent developments in international management research: A review of 20 top management journals.
Journal of Management, 28(3), 277-305.

West, J. and Graham, J. L. (2004). A linguisticbased measure of cultural distance and its relationship to managerial values.

Management International Review, 44(3), 239-260.

Williamson, O. E. (1975). Markets and Hierarchies Analysis and Antitrust Implications Organization. New York, NY: Free Press.

World Bank (1996). World Development Report: From Plan to Market. Washington, DC: Oxford University Press.

World Bank (1993). Kazakhstan: The Transition to a Market Economy. Washington, DC.

World Bank (2014). Doing business: Understanding regulations for small and medium-size enterprises, Retrieved July 1, 2018 from http://doingbusiness.org.

World Bank (2017). World Bank indicators, Retrieved July 1, 2018 from https://data.worldbank.org/indicator/BX.KLT .DINV.CD.WD? end=2017\&locations=KZ\&start=1992.

Wu, S. (2006). Corruption and cross-border investment by multinational firms. Journal of Comparative

Economics, 34, 839-856.

$\mathrm{Xu}, \mathrm{D}$. and Shenkar, O. (2002). Institutional distance and the multinational enterprise. Academy of Management Review, 274), 608-618.

Xu, D., Pan, Y. and Beamish, P. W. (2004). The effect of regulative and normative distances on MNE ownership and expatriate strategies. Management International Review, 44(3), 285-307.

Zhao, H., Ma, J. and Yang, J. (2017). 30 years of research on entry mode and performance relationship: A meta-analytical review. Management International Review, 575), 653-682. 


\section{ABOUT THE AUTHORS}

Wonchan Ra: wonra@hufs.ac.kr

Ms Aigerim Abuova obtained a degree of Master of Arts in International Business from the Department of International Business of Graduate School of Hankuk University of Foreign Studies in Seoul, Korea.

Dr. Wonchan Ra is a professor of international business at the Department of International Business of Graduate School and the Division of Global Business \& Technology of Hankuk University of Foreign Studies in Korea. He earned his Ph.D. degree from Rutgers University School of Management in N.J., U.S.A. His current research interests include international strategic alliances, foreign direct investment and divestment, foreign operation modes, and cross-border knowledge transfer between firms. 
